Flash X-ray (FXR) Accelerator

Optimization Injector Voltage-variation Compensation via Beam-induced Gap Voltage

M. M. Ong

May 13, 2005

IEEE International Pulsed Power Conference 2005 Monterey, CA, United States June 13, 2005 through June 17, 2005 
This document was prepared as an account of work sponsored by an agency of the United States Government. Neither the United States Government nor the University of California nor any of their employees, makes any warranty, express or implied, or assumes any legal liability or responsibility for the accuracy, completeness, or usefulness of any information, apparatus, product, or process disclosed, or represents that its use would not infringe privately owned rights. Reference herein to any specific commercial product, process, or service by trade name, trademark, manufacturer, or otherwise, does not necessarily constitute or imply its endorsement, recommendation, or favoring by the United States Government or the University of California. The views and opinions of authors expressed herein do not necessarily state or reflect those of the United States Government or the University of California, and shall not be used for advertising or product endorsement purposes. 


\title{
FLASH X-RAY (FXR) ACCELERATOR OPTIMIZATION INJECTOR VOLTAGE-VARIATION COMPENSATION VIA BEAM-INDUCED GAP VOLTAGE *
}

\author{
Mike M. Ong \\ Lawrence Livermore National Laboratory, PO Box 808, L-153 \\ Livermore, CA, 94551
}

\begin{abstract}
Lawrence Livermore National Laboratory (LLNL) is evaluating design alternatives to improve the voltage regulation in our injector and accelerator cells of our Flash X-Ray (FXR) machine. The operational peak electron beam current and energy at the x-ray generating target are $3.2 \mathrm{kA}$ and $17 \mathrm{MeV}$. The goal is to create a more mono-energetic electron beam with variation of less than $1 \%$-root-mean-squared (rms). This would allow the beam to be focused more tightly and create an x-ray source with a smaller spot-size. Our injector appears to have significant voltage-variation, and this report describes a technique to appreciably correct the deviations.
\end{abstract}

When an electron beam crosses the energized gap of an accelerator cell, the energy increases. However, the beam with the associated electromagnetic wave also loses a small amount of energy because of the increased impedance seen across each gap. The phenomenon is sometimes called beam loading. It can also be described as a beam-induced voltage at the gap which is time varying. The polarity of this induced voltage is the opposite of the voltage in the injector. The time varying profiles of the injector and induced gap voltage are related through the beam current. However, while the change in magnitude is similar, they are not exactly the same. With the right choice of cell and pulse-power system impedance, the injector variations can be greatly reduced by cancellation, but not totally eliminated.

The FXR injector voltage is estimated to be $2.5 \mathrm{MV}$ peak. The variation is estimated to be about $3.0 \%$-rms for an interval of $60 \mathrm{~ns}$. A simplified mathematical explanation of voltage compensation is given, and an idealized injector profile is used to quantify the effectiveness in a computer simulation. The result calls for a constant cell and pulse-power system impedance of $12.1 \Omega$. For this impedance, the compensated injector voltage-variation is less than $0.1 \%$-rms.

\section{FXR ENERGY REGULATION AND INJECTOR VOLTAGE}

The LLNL FXR is an induction linear accelerator that produces pulsed x-rays and is used regularly and reliably on explosive experiments since its completion in 1982. In recent years, FXR has been incrementally improved, adding double-pulse capability, increasing dose, and reducing $\mathrm{X}$-ray spot-size $[1,2]$.

FXR generates a $3.2 \mathrm{kA}$ electron beam with $17 \mathrm{MeV}$ of energy. Our present beam duration is $70 \mathrm{~ns}$ full-width half-maximum (fwhm). The forward x-ray dose at 1 meter is over $400 \mathrm{Rad}$, and the current spot-size is about $2 \mathrm{~mm}$-fwhm. The peak energy of the injector is estimated to be $2.5 \mathrm{MeV}$.

Beam energy at the electron to x-ray converter target (eq. 1) is proportionate to the voltage of the injector and accelerator, minus the voltage lost as beam loading [3]. This report focuses on a technique to compensate for injector voltage-variations with the beam-induced voltage in the cells indicated in gray in the equation.

$$
E_{V \text { injector }}+E_{V \text { accelerator }}-E_{V \text { beam-induced }}=E_{\text {target }}
$$

This equation has been greatly simplified by eliminating the distributed nature of the acceleration process; nonetheless it represents the concept. The first two terms includes the gap voltage generated by the Marx and Blumlein, along with their interactions with the timeisolation and power feed coaxial lines, and the cell features. The injector voltage has added complexity because of the reflections in the cathode and anode stalks. The accelerator term denoting the unloaded cell voltage is not a part of this discussion.

The third term is derived from the beam-induced gap voltage that launches an electromagnetic (EM) wave into the cell and pulse-power system. Reflections are created at components with different impedances, and they

\footnotetext{
* This work was performed under the auspices of the U.S. Department of Energy by University of California, Lawrence Livermore National Laboratory under Contract W-7405-Eng-48.
} 
eventually affect the voltage in the gap. To concentrate on the compensation analysis, we will assume that the cell and pulse-power system impedance is constant.

The FXR injector diode uses two voltage adders, the cathode is driven by six cells, and a hollow anode stalk is driven by four cells. Adding up the individual cell voltages to get the injector voltage will not be accurate because of the reflections in the stalks. Fortunately, the beam current is routinely and accurately measured. By reversing the diode equation ( 2 and 3 ) we can estimate the voltage profile, $V_{\text {cath-anode }}$, from the beam current, $I_{\text {beam }}$. The constant $\mathrm{k}$ is a conversion number and equal to $8.110^{7}$ for $I_{\text {beam }}=3.2 \mathrm{kA}$ and $V_{\text {cath-anode }}=2.5 \mathrm{MV}$.

$$
\begin{aligned}
& I_{\text {beam }}(t)=\mathrm{k} V_{\text {cath-anode }}(t)^{3 / 2} \\
& V_{\text {cath-anode }}(t)=I_{\text {beam }}(t)^{2 / 3} / \mathrm{k}
\end{aligned}
$$

The beam current at the head and tail of the beam is reduced about $16 \%$ from the peak. The upper portion of the inferred injector voltage is shown in Figure 1, and the beginning and end of the pulse is down about $11 \%$. For precision accelerators, this is a large variation. The average voltage is estimated to be $2.4 \mathrm{MV}$.

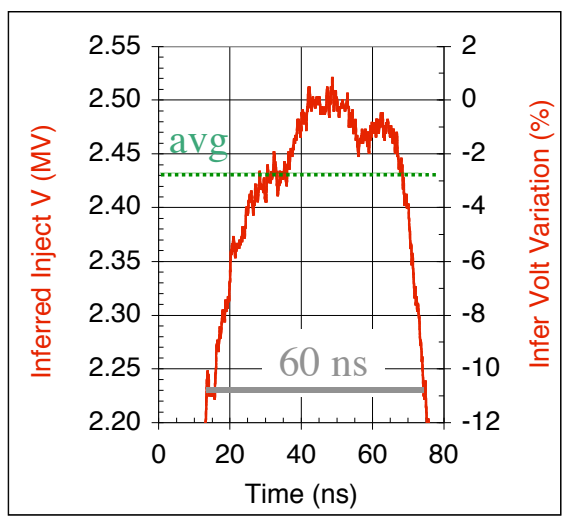

Figure 1. The inferred injector voltage shows a large drop of $11 \%$ for a $60 \mathrm{~ns}$ interval.

The variation is $73 \mathrm{kV}$-rms, or $3.0 \%$-rms for the $60 \mathrm{~ns}$ interval. If we scale this variation by the energy at the target of $17.5 \mathrm{MV}$, the variation is $0.43 \%$-rms. The estimated injector characteristics are shown in Table 1.

\begin{tabular}{|c|c|c|}
\hline $\begin{array}{l}\text { for } 60 \mathrm{~ns} \\
\text { Beam current } \\
\Delta \text { at head and tail }\end{array}$ & $\begin{array}{l}100 \% \\
-16 \%\end{array}$ & $\begin{array}{r}3.2 \mathrm{kA} \\
0.47 \mathrm{kA}\end{array}$ \\
\hline $\begin{array}{l}\mathrm{V}_{\text {cath-anode }} \\
\Delta \text { at head and tail }\end{array}$ & $\begin{array}{l}100 \% \\
-11 \%\end{array}$ & $\begin{array}{l}2.5 \mathrm{MV} \\
\mathbf{2 7 0} \mathbf{k V}\end{array}$ \\
\hline $\begin{array}{l}\mathrm{V}_{\text {cath-anode }} \\
\text { mean } \\
\text { variation }(\mathrm{V}-\mathrm{rms}) \\
\text { variation }(\%-\mathrm{rms})^{*}\end{array}$ & & $\begin{array}{r}2.43 \mathrm{MV} \\
\mathbf{7 3} \mathbf{~ k V} \\
\mathbf{3 . 0 \%}\end{array}$ \\
\hline $\begin{array}{l}\mathrm{V}_{\text {cath-anode }} / \mathrm{V}_{\mathrm{FXR}} \\
\text { variation }(\%-\mathrm{rms}) * *\end{array}$ & & $0.42 \%$ \\
\hline
\end{tabular}

Table 1. Characteristics of inferred injector voltage.

\section{INJECTOR VOLTAGE-VARIATION COMPENSATION}

\section{A. Theory}

In this section, the mathematical basis for injector variation compensation will be presented. The goal is to determine the best cell and pulse-power system impedance that will minimize injector voltage-variation. The target energy equation (1) can be rewritten as a simplified voltage equation (4) by removing the electron charge

$$
V_{\text {injector }}(t)+V_{\text {accelerator }}(t)-V_{\text {induced }}(t)=V_{\text {target }}(t)
$$

Each term is time varying and spatially distributed. The spatial nature of the acceleration process is not important in this discussion. To focus on the voltage-variation compensation concept, we will assume all the voltage sources are collocated.

The beam-induced gap voltage is simply the beam current times the gap impedance. If we assume a constant impedance in the gap, cell and pusle-power system, the induced voltage for a cell is

$$
V_{\text {induced-cell }}(t)=I_{\text {beam }}(t) * \mathrm{Z}_{\text {cell }}
$$

The objective is to balance the change in the injector with the opposite change in the gap. Focusing on just the injector and gap voltage, the difference between the injector and induced voltages, applying equation (5), for $n$ cells is

$$
V_{\text {injector-induced }}(t)=V_{\text {injector }}(t)-I_{\text {beam }}(t) * \mathrm{Z}_{\text {cell }} * \mathrm{n}
$$

Substituting for the current from equation (1), we get

$$
\begin{aligned}
V_{\text {injector-induced }}(t)= & V_{\text {injector }}(t)- \\
& \mathrm{k} V_{\text {injector }}(t)^{3 / 2} * \mathrm{Z}_{\text {cell }} * \mathrm{n}
\end{aligned}
$$

This difference does not have to be zero, only a constant, but the variation needs to be minimized.

$$
V_{\text {injector }}(t)-\mathrm{k} V_{\text {injector }}(t)^{3 / 2} * \mathrm{Z}_{\text {cell }} * \mathrm{n}=\text { constant }
$$


We do this by differentiating the difference equation (8) and setting the result equal to zero.

$$
\begin{aligned}
& \left\{\mathrm{d} V_{\text {injector }}(t) / \mathrm{dt}\right\}- \\
& \left\{\left(\mathrm{k} \mathrm{n} \mathrm{Z}_{\text {cell }}\right)(3 / 2) V_{\text {injector }}(t)^{I / 2}\left(\mathrm{~d} V_{\text {injector }}(t) / \mathrm{dt}\right)\right\}=0 \\
& \left\{1-\left(\mathrm{k} \mathrm{n} \mathrm{Z}_{\text {cell }}\right)(3 / 2) V_{\text {injector }}(t)^{1 / 2}\right\}\left(\mathrm{d} V_{\text {injector }}(t) / \mathrm{dt}\right) \\
& \quad=0
\end{aligned}
$$

There will be injector voltage-variations, so $\mathrm{d} V_{\text {injector }}$ $(t) / \mathrm{dt}$ cannot be equal to zero. Therefore, to minimize the variation in the difference the term, $V_{\text {injector-induced }}(t)$, the result in the \{\} of equation (10) must be zero.

$$
\begin{aligned}
& 1-\left(\mathrm{k} \mathrm{n} \mathrm{Z}_{\text {cell }}\right)(3 / 2) V_{\text {injector }}(t)^{1 / 2}=0 \\
& \mathrm{Z}_{\text {cell }}=1 /\left\{(\mathrm{k} \mathrm{n})(3 / 2) V_{\text {injector }}(t)^{1 / 2}\right\}
\end{aligned}
$$

The optimal cell and pulse-power system impedance depends on the diode conversion constant, the number of cells, and the injector voltage. Because the injector voltage is time varying, the value of $Z_{\text {cell }}$ must also change to make the variation of the difference zero. In theory, perfect compensation is possible, but changing $Z_{\text {cell }}$ in time is extremely difficult. Instead we will choose a single value for $Z_{\text {cell }}$ and use a simple computer simulation, to quantify the effectiveness of compensation.

For an average injector voltage of $2.4 \mathrm{MV}$ and with 44 cells in the accelerator, the gap impedance should be

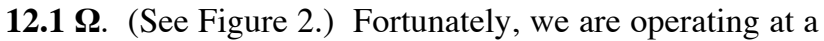
high voltage where the slope of the curve is not very steep, and our uncertainty about the injector voltage will not seriously change the optimal impedance.

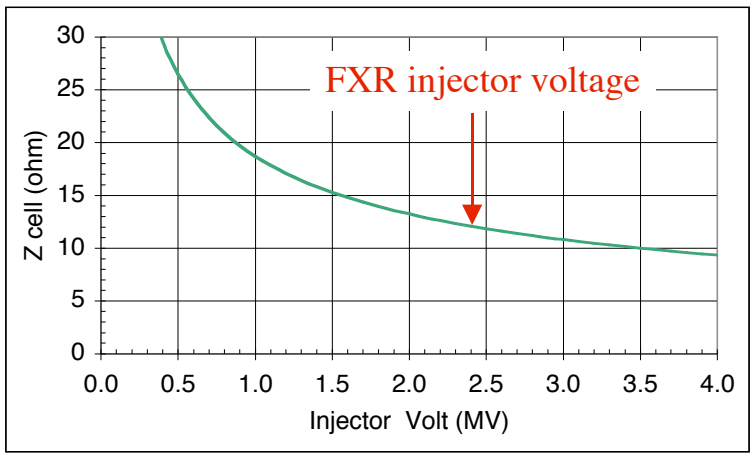

Figure 2. The optimal gap impedance for an injector voltage of $2.4 \mathrm{MV}$ and 44 cells is $12.1 \Omega$

\section{B. Simulation}

A simplified computer simulation is used to quantify the effectiveness of injector voltage-variation compensation. An idealized injector voltage profile is put forth because the real data has noise that would degrade the accuracy of the analysis. The idealized injector voltage is shown in Figure 3 denoted with a dashed line. The $60 \mathrm{~ns}$ waveform is composed of a portion of a sine wave and an offset. The maximum amplitude is set at 2.5 MV, sine wave amplitude was chosen to provide a variation of 3\%-rms to match the inferred variation discussed in the previous section. This profile should reasonably represent the injector voltage.

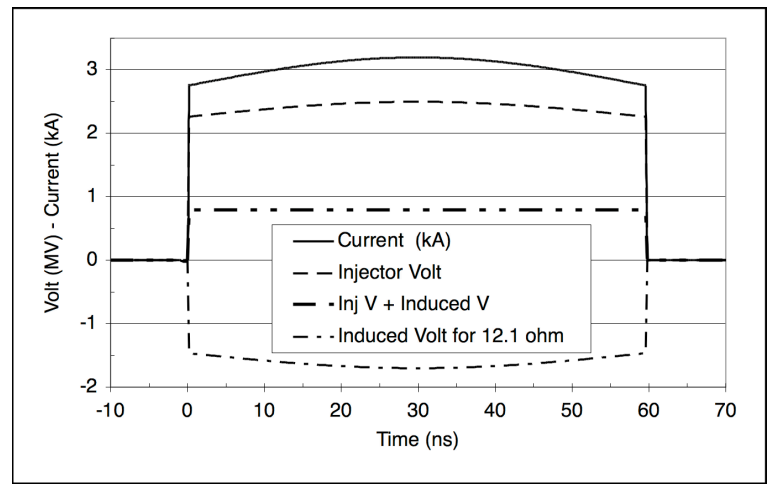

Figure 3. Injector voltage-variation compensation works extremely well for $12.1 \Omega$.

The calculated beam current is shown in the top curve. The total beam-induced voltage for all the cells is negative and is shown in the bottom curve, and to a high degree it has the reverse profile of the injector voltage. The compensated injector voltage is very flat.

The compensated voltage-variation is very low, less than $0.1 \%$-rms. The percentage of variation normalized to the peak injector voltage is shown Figure 4. While not every point can be perfectly corrected, compensation does work exceptionally well.

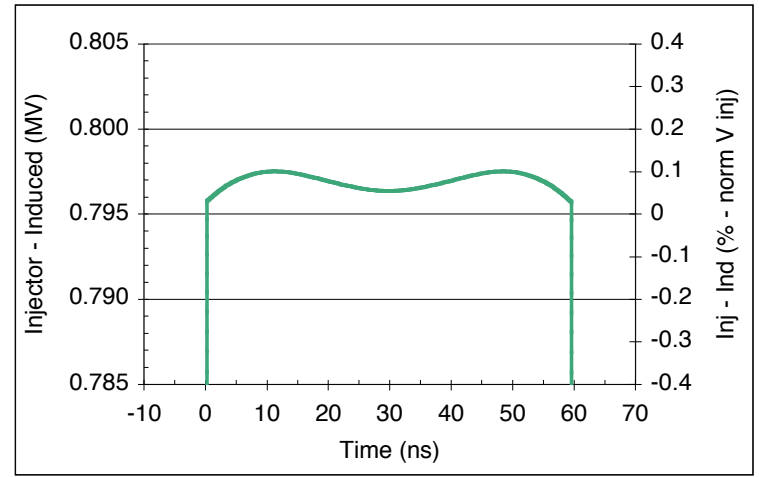

Figure 4. Expanded near perfect compensated injector voltage shows very little variation.

\section{EVALUATION OF ALTERNATIVE GAP IMPEDANCES}

In this section, the effectiveness of compensation with different cell and pulse-power system impedances will be evaluated. Using our model for determining the voltage-variation with an average injector voltage of 2.4 $\mathrm{MV}$, the percentage of compensated injector voltagevariation for a range of impedances is given in Figure 5. Without compensation, the variation is simply the variation of the injector voltage, 3\%-rms. As expected, the optimal impedance of $12.1 \Omega$ derived in the previous 
section produces the minimum variation. Compensation works fairly well on FXR, but this could still be improved.

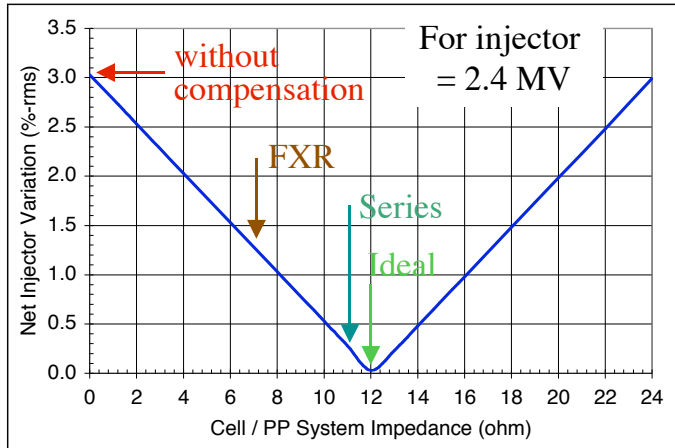

Figure 5. Compensation works on FXR but it could be better.

A comparison of the effectiveness of compensation for four impedances is given in Table 2. Note that the average injector voltage is lowest when compensation works best. There is no free lunch.

Table 2. Comparison of compensation effectiveness for various impedances.

\begin{tabular}{|c|c|c|c|c|}
\hline $\mathrm{Z}_{\text {cell }}$ & $\begin{array}{l}\text { FXR } \\
0.0 \Omega\end{array}$ & $\begin{array}{l}\text { FXR } \\
7.2 \Omega\end{array}$ & $\begin{array}{c}\text { Series } \\
11 \Omega\end{array}$ & $\begin{array}{l}\text { Ideal } \\
12.1 \Omega\end{array}$ \\
\hline $\begin{array}{l}\mathrm{V}_{\text {inj }}-\mathrm{V}_{\text {induced }} \\
\max \end{array}$ & $2.5 \mathrm{MV}$ & $1.49 \mathrm{MV}$ & $0.95 \mathrm{MV}$ & $0.80 \mathrm{MV}$ \\
\hline average & $2.4 \mathrm{MV}$ & $1.45 \mathrm{MV}$ & $0.94 \mathrm{MV}$ & $0.80 \mathrm{MV}$ \\
\hline$\Delta-\max / \min -\%$ & $9.3 \%$ & $6.4 \%$ & $2.3 \%$ & $0.1 \%$ \\
\hline$\Delta$-rms & $73 \mathrm{kV}$ & $30 \mathrm{kV}$ & $7 \mathrm{kV}$ & $<1 \mathrm{kV}$ \\
\hline$\Delta$-rms- $\%$ & $3.0 \%$ & $1.2 \%$ & $0.3 \%$ & $<0.1 \%$ \\
\hline
\end{tabular}

An assumption was made at the beginning of the analysis about the value of the injector voltage. A sensitivity study is presented using the optimal impedance of $12.1 \Omega$. The results are shown in Figure 6. With the optimal cell and pulse-power system impedance, compensation will work over a range of injector voltages. A 10\% change from our estimated average injector voltage of $2.4 \mathrm{MV}$ will increase the compensated variation only $0.15 \%$ to $0.2 \%$. Therefore, the compensation technique requires only a modestly accurate measurement of injector voltage.

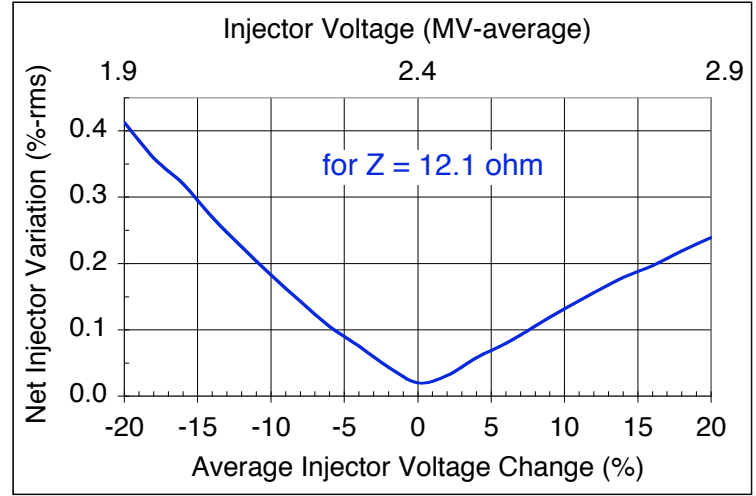

Figure 6. With the optimal impedance, compensation will work well over a range of injector voltages.

The results from this study will be incorporated into a larger accelerator system-model to quantify their effect on total beam energy variations. The compensated injector voltage-variation is reduced to about $40 \%$ of the injector variation.

\section{ACKNOWLEDGMENTS}

I want to acknowledge the contributions of Brian Guidry, Bill DeHope, Blake Kreitzer and Aaron Jones who worked hard to measure FXR cell voltages. The ideas for improving voltage regulations came from many people including Ron Kihara, Dave Goerz, George Vogtlin, Jan Zentler, Bill DeHope and Ray Scarpetti. Because of their vast accelerator experience, I particularly appreciate John Weir's, Tim Houck's, and Glen Westenskow's review of this report. I want to especially thank B-Program and Dave Goerz for funding this work.

\section{REFERENCES}

[1] Multhauf, L.G., "The LLNL Flash X-ray Induction Linear Accelerator", LLNL, Livermore, CA, UCRL-JC-148543, Sept 19, 2002.

[2] Ong, Mike, George Vogtlin, Dave Goerz and Ray Scarpetti, "Flash X-Ray (FXR) Accelerator Optimization", $14^{\text {th }}$ IEEE International Pulsed Power Conference, Dallas, TX, June 2003, pp. 909-12.

[3] Ong, Mike and George Vogtlin, "Flash X-Ray (FXR) Accelerator Optimization - Beam-induced Voltage Simulation and TDR Measurements", Lawrence Livermore National Laboratory, UCRL-TR-205798, April 2004.

[4] Ong, Mike and George Vogtlin, "Flash X-Ray (FXR) Accelerator Optimization - Injector Voltage-variation Compensation via Beam-Induced Gap Voltage", Lawrence Livermore National Laboratory, UCRL-TR205798, April 2004 (full report). 